International Journal of Social Science And Human Research

ISSN(print): 2644-0679, ISSN(online): 2644-0695

Volume 05 Issue 02 February 2022

DOI: 10.47191/ijsshr/v5-i2-04, Impact factor-5.586

Page No: $404-408$

\title{
Application of the Trademark Dilution Doctrine in Brand Dispute Resolution in Indonesia
}

\author{
Irhamnia $^{1}$, Kholis Roisah ${ }^{2}$ \\ ${ }^{1,2}$ Master of Law, Faculty of Law, Universitas Diponegoro
}

\begin{abstract}
Providing protection for well-known brands can be realized by using the doctrine of trademark dilution and bad faith. The aim of this article is to find out the existence of the brand dilution doctrine in Indonesia, and how it is applied to litigation dispute resolution. The research method used is normative juridical with a law and case approach then it is analyzed qualitatively. The results obtained are that Indonesia has not had a regulation on brand dilution yet, but the prohibition against it has been implicitly regulated in the doctrine of bad faith. Enforcement of the trademark dilution doctrine is not carried out in the settlement of disputes between IKEA and IKEMA products. The panel of judges considers that there is no similarity between the two brands, besides that IKEMA is considered not to have violated the provisions of bad faith, so that the Panel of Judges considers IKEMA not guilty. There are no judges in Indonesia who have applied the trademark dilution doctrine because the regulations against it have not been regulated in the law, so to resolve trademark disputes judges use the doctrine of bad faith.
\end{abstract}

KEYWORDS: Trademark Dilution, Dispute, Bad Faith adopted by a country, (2) juridical factors, the validity of legal

\section{INTRODUCTION}

Giving a brand to a product is one of the means to recognize the consumers about a product. A brand is a sign used to identify an item or service that is produced or provided by a particular person or company. Given brand makes easiness for consumers to know the character and quality of a product based on its unique characteristics. To control the use of brand, the regulation is needed to regulate it. Trademark protection in Indonesia is provided through Law Number 20 of 2016 on Marks and Geographical Indications. The definition of a mark according to this law is an image, logo, name, word, letter, number, dimension arrangement, sound, hologram, or a combination of 2 (two) or more of these elements, which are made in two-dimensional or three dimensional form, with the aim of providing a differentiator to the goods/services.

A brand is an object under intellectual property rights that cannot be separated from economic and moral rights. However, the main purpose of branding as a characteristic of a product is still used by irresponsible producers who want to reap profits by using well-known brands on their products. This fraud can be carried out in various forms, such as passing off, trademark dilution to plagiarism on a product, so the percentage of economic rights that should be received by producers is reduced.

Every country has a different way of dealing with the practice of brand dilution. These differences are influenced by norms with their binding power, (3) political factors, supported by political power, and (4) sociological factors, factors that prioritize an empirical approach with several criteria, namely recognition theory, reception theory, or legal facticity criteria.

In this article, the author will analyze the application of the trademark dilution doctrine on trademark disputes resolution that have similar names of brands, so that it is known how the decisions taken by the panel of judges decide disputes on similarity of names on brands in Indonesia. It is necessary to know: 1) How are the regulations regarding trademark dilution in Indonesia? 2) How does it apply to trademark disputes with similar names?

\section{RESEARCH METHOD}

Normative juridical law research is used in this research that focuses on the legal provisions of a country regarding the practice of the trademark dilution doctrine in dispute resolution in Indonesia. The data used in this study are primary data, secondary and tertiary data. The primary data used is Law Number 20 of 2016 on Marks and Geographical Indications, the decision to settle a trademark dilution dispute is secondary data, while books and data from the government's official website are tertiary data. The analysis used in this research is descriptive qualitative analysis, which is an analysis that describes the application of the trademark dilution doctrine in the settlement of trademark disputes in Indonesia. various factors, such as (1) philosophical factors, applicable legal norms in accordance with the philosophical values. 


\section{Application of the Trademark Dilution Doctrine in Brand Dispute Resolution in Indonesia}

\section{RESULT AND DISCUSSION}

\section{A. Trademark Dilution Overview}

Trademark dilution occurs when a third party uses a trademark that is similar to a well-known brand that causes consumer perceptions to the product and harm a well-known brand, or it can also be interpreted that. When a well-known brand is used by anyone who is not related to the brand, its uniqueness as the only brand will be lost. (Jain 2018) Two or more products with the exact same brand will cause confused to the consumers, especially if the brand is the same product and store. (Kimt, 2002) By giving the same brand to consumers of a product, consumers will assume that they are in the same brand, especially on well-known brands, so it can influence consumers to buy something. Trademark dilution occurs in two goods with very similar brands, but it has different sales sectors, so product names with the same brand do not occur in brand dilution. Protection against brand dilution based on protecting the quality of the distinguishing power of well-known brands and protecting the reputation of those who try to tarnish well-known brands, not on consumer confusion about the product or the competition between them. (Dwisvimiar 2016) Basically trademark dilution is created to protect the owner and the brand itself, not the consumer. (Kimt 2002)

\section{B. Trademark Dilution in Indonesia}

Trademark dilution is a new term whose provisions regarding it have not been regulated in Law Number 20 of 2016 on Marks and Geographical Indications, but the handling of it is written implicitly in Article 21 section 1 letter $\mathrm{b}$ and $\mathrm{c}$ namely the application for registration of a mark will be rejected if it has similarities in principle or in its entirety to (1) a well-known mark belonging to another party in the form of similar goods/services (2) a well-known mark belonging to party in the form of dissimilar goods/services that meet certain requirements. Although it has not been regulated directly, it can be understood that the use of a brand that has similarities even though it is not in a similar item is an act that violates and can attack the reputation of the brand which imitates it. (Roisah and Setiyono 2019)

The implicit mention of brand dilution by Law Number 20 of 2016 on Marks and Geographical Indications in the trademark registration regulation indicates that prevention of the practice of brand dilution can be carried out at the time the mark is registered. A registered mark can be rejected if it fulfills one of the refusal requirements in Article 21 Section 1 and 2 of the Law Number 20 of 2016 on Marks and

Geographical Indications, on the grounds in Section 3 that the registrant committed a bad faith. (UURI No. 20 of 2016) The scope of bad faith includes fraud, misdirection, and neglect of legal obligations to gain profits. It can also be interpreted as an untruthful act to achieve a dishonest goal that is done consciously. (Mardianto 2010) The definition of bad faith according to Black's Law Dictionary is "the opposite of good faith, generally implying or involving actual or constructive fraud, or a design to mislead or deceive another, or a neglect or refusal to fulfill some duty or some contractual obligation, not prompted by an honest mistake as to one's rights or duties, but by some interested or sinister motive."(Black 1911) "An applicant with bad intentions" in the explanation of Law Number 20 of 2016 on Marks and Geographical is an applicant who is reasonably suspected in registering his trademark for the sake of his business causing conditions to have the intention to imitate, plagiarize, or follow the mark of unfair business competition, deceive, or mislead consumers. (UURI No. 20 of 2016)

Verification of bad faith can be prevented in the trademark registration process to avoid trademark dilution. Trademark registration in Indonesia is submitted at the Directorate General of Intellectual Property of the Republic of Indonesia Office by online or offline. After applicant registration is submitted, the inspection of the mark may be carried out by a functional official who is appointed and dismissed by the Minister to carry out his duties. Mark applications submitted will be examined by the functional official to ensure that substantive requirements are fulfilled.

Substantive requirements are conditions that must be met by the applicant so that the mark is entitled to legal protection. Substantive requirements include two requirements, namely absolute and relative requirements: (Roisah and Setiyono 2019)

1) The absolute requirement that must be met by the applicant or do not contain the things in Article 20 of the Law Number 20 of 2016 on Marks and Geographical Indications, (Roisah and Setiyono 2019) which reads as follows: Letters a: "Contrary to state ideology, statutory regulations, morality, religion, decency, or public order." Letter b: "The same as, relating to, or only mentioning the goods and/or services for which registration is requested." Letter c: "It contains elements that can mislead the public about the origin, quality, type, size, type, purpose of use of goods and/or services which registration is requested or is the name of a protected plant variety for similar goods and/or services. " Letter d: "It contains information that is not in accordance with the quality, benefits, or efficacy of the goods and/or services produced. " Letter e: "It lacks discrimination." and/or Letter f: "It is a common name and/or symbol of public pro perty." (UURI No. 20 of 2016 )

2) The relative requirements is a mark that can be rejected by the Directorate General of Intellectual Property of the Republic of Indonesia Office because it fulfills the elements of Article 21 of the Law Number 20 of 2016 on Marks and Geographical Indications, (Roisah and Setiyono 2019) which reads as follows: Section 1: "The application is rejected if the Mark has similarities in principle or in its entirety with: a. Registered marks belonging to another party or previously requested by another party for similar goods and/or services; b. Well-known marks belonging to other parties for similar goods and/or services; c. Well-known marks belonging to other parties for goods and/or services of a different kind that meet certain requirements; or $\mathrm{d}$. 


\section{Application of the Trademark Dilution Doctrine in Brand Dispute Resolution in Indonesia}

Registered Geographical Indications." Section 2: "The application is rejected if the Mark: a. Constitutes or resembles the name or abbreviation of the name of a famous person, photo, or name of a legal entity owned by another person, except with the written consent of the entitled party; b. Imitates or resembles the name or abbreviation of the name, flag, symbol or symbol or emblem of a country, or national or international institution, except with written approval from the competent authority; or c. Imitates or resemble an official sign or stamp or seal used by a state or government agency, except with the written approval of the competent authority." Section 3: "An application is rejected if it is submitted by an applicant with bad faith." (UURI No. 20 of 2016)

An examination using these two conditions provides an opportunity for the examiner to apply the doctrine of mark dilution, namely examining the trademark being applied for from the overall similarity content and principal similarity with a well-known mark of the same or dissimilar type based on the provisions of Article 21 Section 1 letter $\mathrm{c}$. In carrying out a trademark inspection, the examiner is equipped with a trademark inspection guideline, namely the Regulation of the Minister of Law and Human Rights Number 67 of 2016 concerning Trademark Registration. (Roisah and Setiyono 2019) After the inspection is carried out and the trademark applied for meets the two requirements that have been described, the trademark applicant is declared to be in good faith and brands can be registered.

Table 1: Trademark data registered with the Directorate General of Intellectual Property of the Republic of Indonesia Office in 2017-2019:(Data n.d.)

\begin{tabular}{|l|l|l|l|}
\hline Year & Application & Accepted & Rejected \\
\hline 2017 & 53.493 & 41.538 & 9.581 \\
\hline 2018 & 60.330 & 45.877 & 8.875 \\
\hline 2019 & 71.291 & 37.636 & 3.588 \\
\hline
\end{tabular}

Based on the data in the table above, it can be concluded that application for trademarks in Indonesia has increased every year. Brand acceptance in 2017 and 2018 has increased, then decreased in 2019, while brand rejection has decreased every year. However, not all applications get a decision on acceptance or rejection in the same year.

A study conducted by Dwisvimiar stated that the existence of a bad faith doctrine was not enough to overcome the problem of trademark dilution. The research conducted on the Law 15 of 2001 on Trademarks still has relevance to the

Law Number 20 of 2016 on Marks and Geographical

Indications, these two laws do not regulate brand dilution and only use the doctrine of bad faith. According to Dwisvimiar, the Law 15 of 2001 on Trademarks does not regulate the dilution of marks. In this Law, Article 6 section 1 regulates trademark infringement on similar goods, while section 2 applies to mark with dissimilar goods. This is also contained in the Article 21 section 1 letters b and $\mathrm{c}$ of the Law Number 20 of 2016 on Marks and Geographical Indications. These articles are related to trademark infringement, even though they are implied about the regulations regarding trademark dilution. According to Dwisvimiar, the doctrine of trademark infringement is different from the doctrine of trademark dilution, in addition to that the substance of the protection is different from another. So, what needs to be changed in this regulation is to separate the two provisions (mark dilution and mark infringement) into different articles. The advantages obtained in this way are: (1) there is no need to make separate regulations regarding mark dilution, because both are part of the trademark law; (2) not to require a lot of elaboration in one article, it is enough to explain in the explanation section; (3) to provide legal certainty, Indonesia is a country that adheres to the Civil Law System that uses legislation as a source of law. While the disadvantages are: (1) providing the same interpretation between brand dilution and brand infringement; (2) the law becomes swollen due to the existence of a new doctrine and has implications for the legal consequences of the new doctrine; (3) requiring communication regarding the implementation and proceeding to the public regarding the new doctrine, that this brand dilution doctrine provides wider protection for brand owners. (Dwisvimiar 2016)

One example of a case concerning brand dilution in Indonesia that is interesting to discuss is the case between IKEA and IKEMA in 2011. IKEA through inter IKEA Systems BV sued PT. Angsa Daya, the excuse given is that IKEA is a product that has been registered since 1943 in goods class are class 21 (household appliances), 24 (textiles), 11 (installation of lighting, heating, cooling, etc.), 35 (office equipment) and 42 (industrial research services), while IKEMA is in class 19 goods (materials non-metallic buildings). IKEA sued IKEMA because they felt that they had been imitated, plagiarized and piggybacked on IKEA's fame. They assumed that these similarities can deceive consumers. (Permata et al. 2019) At the first instance, the panel of judges granted the cancellation of the IKEMA mark, this decision was upheld at the cassation level. However, at the level of judicial review, the judicial review panel stated that: (a) the IKEA brand did not have anything in common with IKEMA as stated by Angsa Daya regarding the origin and pronunciation of IKEMA which came from the Chinese language; (b) the IKEMA mark registered in class 19 is not an item of the same type or class as the IKEA mark listed in class 11,21, 24, 35, 42; (c.) the application of Article 6 section 2 regarding "well-known marks" related to Government Regulations that require requirements, and so far there has not been. (Permata et al. 2019) 


\section{Application of the Trademark Dilution Doctrine in Brand Dispute Resolution in Indonesia}

Based on this case, there is uncertainty about the trademark dilution case, thus giving confusion to the judicial review panel due to the lack of similarity in class goods and the absence of definite regulations governing brand dilution. Therefore, based on this decision, the regulation regarding trademark dilution which is "implied" in the Law Number 20 of 2016 on Marks and Geographical Indications cannot provide a strong legal standing for its practice.

The results of the discussion of the research above are that Indonesia has not had a brand dilution regulation yet and only writes it implicitly in Article 21 section 1 letter $\mathrm{b}$ and $\mathrm{c}$ that has not been able to resolve the trademark dilution dispute properly. This happened in the dispute between IKEA and IKEMA with the final decision that IKEMA did not carry out trademark dilution because it had a different product and meaning. In addition, the uncertain provisions on mark dilution were also the reason for the judge to reject IKEA's application in this dispute.

The view obtained from this case is that the function of intellectual property rights as protection of economic rights as a result of intellectual creativity (Arif and Rosni 2018) and protection against brand dilution is not achieved, because even though it is clear that the second brand has the name that is almost similar to a well-known brand. The protection to wellknown brands is not given because it is considered that the two products sell different classes of products. The purpose of brand dilution protection is to protect other brands that use well-known brands with different products, even though there is no confusion about the product or the origin of the product, because it will reduce the uniqueness of the brand or even the well-known brand will weaken over time. (Nadya Valerie 2019) It is feared if this dispute does not get the right decision, things that can be avoided with brand dilution effect will happen to famous brands.

The doctrine of bad faith has not been able to overcome the problem of brand dilution in Indonesia. Indonesia which has not assigned legal provisions yet for brand dilution, relies on the doctrine of bad faith in Article 21 section 3 of the Law Number 20 of 2016 on Marks and Geographical Indications to overcome this problem, but in the case that occurred between IKEA and IKEMA was deemed that there was no bad faith behavior by IKEMA. Good faith whose assessment can be carried out relatively (done by assessing behavior) and subjectively (done with common sense and fairness.) (Lumopa, Suherman, and Haryanto 2018) Subjective assessment should be carried out on IKEMA trademark registration because it can be ascertained that the mark bears resemblance to the IKEA brand, but the decision in this case does not consider IKEMA to have bad faith, so that the implied protection against brand dilution by Article 21 Section 1 letters b and c of the the Law Number 20 of 2016 on Marks and Geographical Indications cannot be used as a benchmark for enforcement of brand dilution.

Beside the case that occurred in the dispute between IKEA and IKEMA, research conducted by Kholis Roisah and Joko Setyono stated that no judges in Indonesia have not applied the trademark dilution doctrine yet. This is concluded from three cases of wellknown brands who report other brands because they are considered to resemble and damage the reputation. Based on the three brands, there is no judge's decision that uses the trademark dilution doctrine, but they use the bad faith doctrine, this is considered not to damage the reputation of a well-known brand. In addition, there is no written rule in the Law Number 20 of 2016 on Marks and Geographical Indications that regulates trademark dilution, this is the main reason the judges have not been able to use the trademark dilution doctrine because Indonesia is a country that adheres to Civil Law, so the application of the bad faith doctrine is considered sufficient to resolve cases of wellknown brand. (Kholis and Joko).

\section{CONCLUSION}

Indonesia has not regulated the law on trademark dilution, the regulation is only implied through Article 21 section 1 letters $\mathrm{b}$ and $\mathrm{c}$, and it uses the doctrine of bad faith to resolve trademark dilution disputes. The dispute resolution between IKEA and IKEMA does not use the trademark dilution doctrine. IKEA's application was rejected because it was considered that IKEMA's products did not sell the same products as IKEA and the name taken was not inspired by IKEA. The reason for bad faith is not found in this dispute decision, even though when it is viewed with common sense, the IKEMA brand is very similar to the IKEA brand, this can endanger the sustainability of IKEA because it can eliminate the uniqueness of its products. The absence of regulations regarding trademark dilution in the Law Number 20 of 2016 on Marks and Geographical Indications is the main reason for judges in deciding cases of name equality on well-known brands, so the doctrine of bad faith is considered sufficient to overcome these problems. It can be concluded that the use of the brand dilution doctrine has not had a deep understanding of the concept yet because the use of reasons in the decision still leads to the same product not to different types of products, so it is not considered a violation of the law.

\section{REFERENCES}

1) Antons, By Christoph. 2006. "Intellectual Property Law in Southeast Asia: Recent Legislative and Institutional Developments 12 . Two Decades of Change 3 . Legislative and Institutional Reforms in Individual Countries." Order A Journal On The Theory Of Ordered Sets And Its Applications 1-12.

2) Arif, Muhammad, and Rosni Rosni. 2018. "Utilization and Management of Intellectual Property Rights (IPR) as an Entrepreneurship Development Strategy.” Journal of Geography 10(1):98. doi:10.24114/jg.v10i1.8632.

3) Barizah, Nurul. 2017. "The Development of ASEAN's Intellectual Property Rights Law; from Trips Compliance to Harmonization.” Indonesia Law Review 7(1):95-112. 


\section{Application of the Trademark Dilution Doctrine in Brand Dispute Resolution in Indonesia}

4) Benuf, Kornelius, Muhamad Azhar, Agency Staff, Legal Consulting, Faculty of Law, Diponegoro University, Legal Research, and Contemporary Issues. 2020. "Legal Research Methodology as an Instrument to Unravel Contemporary Legal Problems Journal of Gema Keadilan Journal of Gema Keadilan.” 7:20-33.

5) Black, Henry Campbell. 1911. "A Law Dictionary.-Containing Definitions of the Terms and Phrases of American and English Juridprudence, Ancient and Modern.” Michigan Law Review 9(5):455. doi: 10.2307/1275199.

6) Data, Intellectual Property Base. n.d. Brand. Indonesia.

7) Dwisvimiar, Inge. 2016. "Regulation of the Dilution of Trademark Doctrine as a Legal Protection Effort for Famous Trademarks in Indonesia." The pulpit of the Law 28(2):232- 49.

8) Isaac. 2017. Legal Research Methods and Writing Thesis, Thesis, and Dissertation.

9) Jains, Aashima. 2018. "Trademark Dilution: Infringing Efforts to Mint Profits." International Journal of Law 4(2):192-96.

10) Kimt, Paul Edward. 2002. "Preventing Dilution Of The Federal Trademark Dilution Act: Why The Ftda Requires Actual Economic Harm.” (719).

11) Llewelyn, David, and David Llewelyn. 2005. "Institutional Knowledge at Singapore Management University Trade Mark Dilution in Singapore: The Aftermath of McDonald 's v MacTea Trade Mark Dilution in Singapore: The Aftermath of McDonald's v MacTea." 138-51.

12) Lumopa, Farly, Suherman, and Imam Haryanto. 2018. "Good Faith in Registration of Famous Marks in Indonesia." Director 5(2):277-93.

13) Mahfuz, Abdul Latif. 2019. "Factors Influencing Legal Politics in a Formation." Journal of Legal Assurance And Justice 1(1):43-57.

14) Mardianto, Agus. 2010. "Removal of Trademark Registration Based on Third Party Lawsuits." Journal of Legal Dynamics 10(1):43-50. doi: 10.20884/1.jdh.2010.10.1.137.

15) Nadya Valerie, Edbert Seligshan Horman. 2019. "Legal Protection Against Christian Dior Famous Brands From the Concept of Trademark Dilution.” Journal of Scholar of Law 4(2):231-42. doi:10.3376/jch.v4i2.132.

16) Permata, Rika Ratna, tasya saphiranita, and Biondy Utama. 2019. "Case Overview of Brand Dilution in Indonesia and Thailand.” Journal of Law Ius Quia Iustum 26(1):1-20. doi: 10.20885/iustum.vol26.iss1.art1.

17) Quek, Egina, and One Legal LLC Shawn Poon. 2018. "Trade Mark Litigation in Singapore: Overview."

18) Roisah, Kholis, and Joko Setiyono. 2019. "Implementation of Trademark Dilution in Enforcement of Legal Protection for Famous Trademarks in Indonesia." Law Reform 15(2):303-19. doi: 10.14710/lr.v15i2.26188.

19) UURI No. 20 years. 2016. "The Republic of Indonesia Law No. 20 Year 2016 Regarding Brands And Geographical Indications." 